\title{
Validity of the career embeddedness scale as predictor of affective commitment
}

\begin{tabular}{|c|c|}
\hline \multicolumn{2}{|c|}{$\begin{array}{l}\text { Authors: } \\
\text { Nadia Ferreira }^{1} \text { (D) } \\
\text { Melinde Coetzee }^{2} \text { (D) } \\
\text { Ingrid Potgieter }\end{array}$} \\
\hline \multicolumn{2}{|c|}{$\begin{array}{l}\text { Affiliations: } \\
{ }^{1} \text { Department of Human } \\
\text { Resource Management, } \\
\text { College of Economic and } \\
\text { Management Sciences, } \\
\text { University of South Africa, } \\
\text { Tshwane, South Africa }\end{array}$} \\
\hline \multicolumn{2}{|c|}{$\begin{array}{l}{ }^{2} \text { Department of Industrial } \\
\text { and Organisational } \\
\text { Psychology, College of } \\
\text { Economic and Management } \\
\text { Sciences, University of } \\
\text { South Africa, Tshwane, } \\
\text { South Africa }\end{array}$} \\
\hline \multicolumn{2}{|c|}{$\begin{array}{l}\text { Corresponding authc } \\
\text { Nadia Ferreira, } \\
\text { ferren@unisa.ac.za }\end{array}$} \\
\hline \multicolumn{2}{|c|}{$\begin{array}{l}\text { Dates: } \\
\text { Received: } 27 \text { Sept. } 2021 \\
\text { Accepted: } 06 \text { Dec. } 2021 \\
\text { Published: } 11 \text { Feb. } 2022\end{array}$} \\
\hline \multicolumn{2}{|c|}{$\begin{array}{l}\text { How to cite this article: } \\
\text { Ferreira, N., Coetzee, M., \& } \\
\text { Potgieter, I. (2022). Validity of } \\
\text { the career embeddedness } \\
\text { scale as predictor of affective } \\
\text { commitment. SA Journal of } \\
\text { Industrial Psychology/SA } \\
\text { Tydskrif vir Bedryfsielkunde, } \\
48(0) \text {, a1956. https://doi. } \\
\text { org/10.4102/sajip.v48i0.1956 }\end{array}$} \\
\hline \multicolumn{2}{|c|}{$\begin{array}{l}\text { Copyright: } \\
\text { (c) 2022. The Authors } \\
\text { Licensee: AOSIS. This } \\
\text { is licensed under the } \\
\text { Creative Commons } \\
\text { Attribution License. }\end{array}$} \\
\hline \multicolumn{2}{|l|}{ Read online: } \\
\hline 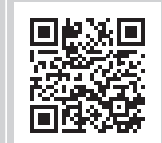 & $\begin{array}{l}\text { Scan this QR } \\
\text { code with your } \\
\text { smart phone or } \\
\text { mobile device } \\
\text { to read online. }\end{array}$ \\
\hline
\end{tabular}

Orientation: In times of rapid change, organisations have a dire need for workers who remain psychologically attached and committed to their work for optimal sustainable organisational performance and survival.

Research purpose: The aim of the study was to explore the construct validity of the Career Embeddedness Scale (CES) as predictor of individuals' affective commitment.

Motivation for the study: There is a paucity of research regarding the construct validity of the CES and whether it predicts an individual's affective commitment.

Research approach/design and method: The study involved a cross-sectional quantitative survey on a sample of employees in the services industry. The sample consisted of African (South African $=70 \%$ and Zimbabwean $=15 \%)$ and European $(15 \%)$ participants $(N=290)$, with a mean age of 38.58 years.

Main findings: Confirmatory factory analysis (CFA) analysis provided evidence of the construct validity of the CES in predicting affective commitment.

Practical implications: The use of the CES measure of the degree to which organisational career support conditions fulfil individuals' psychological career needs potentially provides opportunity for engagement with the organisation and individual on career development issues in response to workplace changes that potentially affect employees' psychological attachment to the organisation.

Contribution/value-add: The study contributed to the career development research literature by providing valuable psychometric information on the CES and its application in the personenvironment (P-E) fit theory and work context.

Keywords: career embeddedness; personal career fit; career needs support; personenvironment fit; affective commitment.

\section{Introduction}

Career embeddedness (i.e. the deep-seated situatedness of the career in an organisation) and affective commitment (i.e. individuals' emotional attachment to and identification with the organisation) have come under scrutiny amidst contemporary changing work conditions (Akkermans, Richardson, \& Kraimer, 2020; Cho, 2020; Ferreira \& Coetzee, 2020; Meyer \& Allen, 1991; Zhu, Kim, Milne, \& Park, 2021). The pandemic has revived individuals' career agency and self-regulation in fulfilling their career goals amidst the uncertainty of changing job markets; individuals appear to have become more committed towards the management of their careers rather than being committed to the companies for which they work (Restubog, Ocampo, \& Wang, 2020). In times when organisations can no longer offer long-term job security and employment (Restubog et al., 2020; Zhu et al., 2021), the question now arises to what extent does individuals' restored need for taking control for the fulfilment of career needs influence their affective commitment towards the organisation? In times of rapid change, organisations have a dire need for workers who remain psychologically attached and committed to their work for optimal sustainable organisational performance and survival (Coetzee \& Bester, 2021; Sungu, Weng, \& Kitule, 2019).

In this article, we explore career embeddedness as a predictor of individuals' affective commitment. Career embeddedness is a recent construct denoting the career identity as being deeply situated within the organisation because of a web of career-supportive organisational practices and relational networks, including a satisfactory fit between personal career values and those of the organisational culture and values (Ferreira \& Coetzee, 2020). The construct of career embeddedness 
evolved from the basic tenets of person-environment (P-E) fit theory and research (Guan, Deng, Fan, \& Zhou, 2021; Jiang \& Jiang, 2015; Van Vianen, 2018). The P-E fit theory (Guan et al., 2021; Van Vianen, 2018) suggests that individuals' careers take shape at the intersection between the social environment (e.g. organisation) that provides career and work opportunities in lieu of individuals' psychological career needs in exchange for their talents and capabilities that add to the performance and sustainability of the organisation (Coetzee \& Schreuder, 2021). Job and career satisfaction and a sense of career embeddedness generally result from a strong compatibility (P-E fit) between an individual and the work environment (Darrow \& Behrend, 2017; Ferreira \& Coetzee, 2020). The embedded or disembedded nature of an individual's career is closely dependent on the presence (or absence) of a system of supportive practices and relations that facilitate (or thwart) the psychological fulfilment of career development needs and the expression of personal career values (Coetzee \& Bester, 2021; Vondracek, Ford, \& Porfeli, 2014).

The job embeddedness research literature echoes this line of thought by demonstrating thelink betweenjob embeddedness and staff retention, turnover intention, job and career satisfaction and organisational commitment (Holtom \& Darabi, 2018; Huang, Cheng, Sub, Jiang, \& Lin, 2021; Potgieter, Coetzee, \& Ferreira, 2019). However, being a recent construct coined by Ferreira and Coetzee (2020), research on career embeddedness and people's affective commitment to the organisation seems presently non-existent. Whilst job embeddedness focuses on the forces (i.e. links, fit, sacrifice) that influence individuals to become tied to the organisation (Holtom \& Darabi, 2018; Mitchell, Holtom, Lee, Sablynski, \& Erez, 2001), the construct of career embeddedness deepens understanding of the psychological career identity needs individuals seek to fulfil in their interaction with an organisation or social system; satisfaction of basic career needs in a work environment evokes a sense of situatedness in the P-E interaction process (Ferreira \& Coetzee, 2020). Drawing from the work of Coetzee and Bester (2021) and Vondracek et al. (2014), we argue that the psychological fulfilment of basic career development needs including the expression of career values in the P-E interaction facilitates individuals' sense of career embeddedness, and hence their affective commitment towards the organisation.

The objective of the present study was to test the construct validity of the Career Embeddedness Scale (CES) of Ferreira and Coetzee (2020) in predicting Meyer and Allen's (1997) construct of affective commitment. By doing so, the study seeks to advance knowledge of the influence of a psychological state of career embeddedness on individuals' affective commitment from Guan et al.'s (2021) reconceptualised perspective of $\mathrm{P}-\mathrm{E}$ fit theory.

\section{Literature review}

\section{Person-environment fit and career embeddedness}

Embeddedness theory of cognition (Malinin, 2016) postulated that people are active agents and explorers of their environment who habitually scan the world for information and resources that are relevant to them. Career embeddedness as a psychological career construct refers to Vondracek et al.'s (2014) idea that the interaction between individuals and their employment environment constrain or enable the possible career behaviours of the individual, which in turn, influence $\mathrm{P}-\mathrm{E}$ fit evaluation processes that emerge from the interaction.

The modern P-E fit theory of Guan et al. (2021) views P-E fit as processes of career identity management (i.e. supplementary fit: individuals' evaluation of the match between self-defining career identity-related career values, abilities, interests and job roles) and social exchanges (i.e. complementary fit) in relation to the work environment.

Complementary fit processes of career identity management involve evaluations of demand-abilities fit (D-A fit) and needs-supply fit (N-S fit) as indicators of the quality of social exchanges. Individuals expect to receive favourable conditions and rewards (N-S fit) from the environment in return for the capabilities (knowledge, skills, abilities: D-A fit) they are required to utilise to fulfil role expectations (Guan et al., 2021). Individuals' perceptions of P-E fit (i.e. supplementary fit, N-S fit and D-A fit) underpin the selfregulatory processes whereby they manage their careers in social contexts (Guan et al., 2021; Kooij, 2020; Kooij, Zacher, Wang, \& Heckhausen, 2020).

Similar to Guan et al.'s (2021) conceptualisation of P-E fit, career embeddedness alludes to the fulfilment of psychological career identity needs. Proponents of P-E fit theory (see Jiang, 2017; Sampaio, Cardoso, Rossier, \& Savickas, 2021; Van Vianen, 2018) positioned psychological needs as a core concept to explain the manner in which individuals engage in self-regulatory career behaviour to successfully adapt to changing work contexts. Career adaptation (and by implication career embeddedness) results from the fulfilment of psychological needs in the work context flowing from a correspondence between personal career identity needs and the work environment conditions (Sampaio et al., 2021). We argue that individuals' sense of supplementary and complementary P-E fit influences their state of career embeddedness; individuals feel more deeply situated in a specific organisation-based career when their basic psychological career identity needs are fulfilled.

Psychological needs in the career embeddedness context relate to what individuals feel they lack, which in turn moves them to seek experiences of supplementary fit (career identity congruence) and complementary fit (D-A fit and N-S fit) in environments in which they feel more secure (Guan et al., 2021; Sampaio et al., 2021; Savickas, 2013; Vondracek et al., 2014). Optimal P-E congruence results from a satisfactory match between specific characteristics of the person and the environment (career identity values and D-A fit (the degree to which a person's abilities meet the demands of the environment) and N-S fit (the degree to which an environment meets a person's needs: Darrow \& Behrend, 2017; Jiang, 2017; Xu \& Tracey, 2014). 


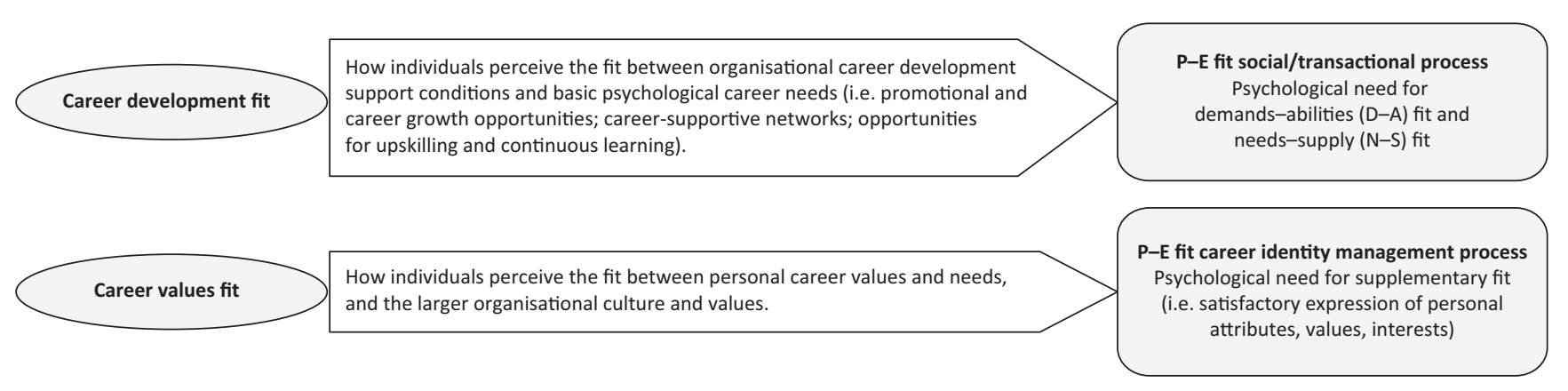

P-E, person-environment; D-A, demand-abilities; N-S, needs-supply.

FIGURE 1: Facets of career embeddedness.

As shown in Figure 1, Ferreira and Coetzee (2020) differentiated between two dimensions of psychological career identity needs underpinning the construct of career embeddedness: (1) career development fit, and (2) career values fit. Career development fit relates to the psychological need for making career progress having future career options and promotional opportunities in the organisation. Career development fit also involves a need for relationship networks and organisational conditions that support one's career growth, upskilling and continuous learning for enhanced marketability and employability. Drawing from P-E fit theory (Guan et al., 2021), the career development fit facet of career embeddedness relates to individuals' psychological need for D-A fit (i.e. need for upskilling and continuous learning opportunities) and N-S fit (i.e. promotional opportunities and career development supportive relations and conditions). These two dimensions of complementary P-E fit involve individuals' evaluation of the quality of the social exchange between themselves and the organisation. Organisational career development support conditions such as promotional and continuous learning opportunities and career-supportive networks of relations were found to enhance career certainty, work performance, career satisfaction and affective commitment (Coetzee \& Bester, 2021; Durr II \& Tracey, 2009).

Career values fit relates to the perceived compatibility between personal career identity needs and career values and those of the organisational culture and values. Drawing from Guan et al.'s (2021) P-E fit theory, the career values fit facet of career embeddedness relates to the supplementary fit dimension of $\mathrm{P}-\mathrm{E}$ fit, which views career development needs and career values as playing a fundamental role in the career identity management process. Career development needs and career values serve as relatively stable goals that direct individuals towards their goals and that allow needs satisfaction in a societal context (Sampaio et al., 2021). According to Super (1990), life and career satisfaction is dependent on the degree to which individuals find an outlet for their abilities, needs, values, interests and career selfconcepts. Career values are generally expressed by individuals to guide their career choices and to define subjective career success (Abessolo, Hirschi, \& Rossier, 2021).

Proponents of P-E fit theory (Guan et al., 2021; Savickas, 2013; Van Vianen, 2018; Vondracek et al., 2014) also argue that a perceived fit between personal values and environmental characteristics foster psychological need fulfilment and wellbeing. Intrinsic career values have been associated with job and career satisfaction (Abessolo et al., 2021; Hall, Yip, \& Doiron, 2018). Perceived fit also engenders greater levels of satisfaction, commitment and engagement (Ackerman \& Kanfer, 2020; Vantilborgh et al., 2013).

Generally, organisational contexts shape individuals' motivation (and by implication career embeddedness) because they create different opportunities for and constraints upon psychological career needs satisfaction (Sampaio et al., 2021). An organisation's career culture is seen to shape individuals' career motivations, decisions and behaviours; perceptions of poor fit between personal career values and needs and those of the organisational career culture may result in low organisational commitment and higher turnover intention (Coetzee, 2018).

\section{Career embeddedness and affective commitment}

Affective commitment denotes a social-emotional attachment with the organisation and the importance and meaningfulness of the organisation and its people to the individual in their job and career (Meyer \& Allen, 1991). In this regard, affective commitment alludes to an emotional bond of closeness and psychological identification with the organisation stemming from the fulfilment of the basic human need for belonging and being cared for by the organisation (Rhoades \& Eisenberger, 2002; Weng, Wu, McElroy, \& Chen, 2018). On the other hand, career embeddedness is anchored in the career identity and relates to a sense of deep-seated situatedness in a work environment because of cognitive evaluations of supplementary and complementary P-E fit based on the degree of psychological career identity needs and values fulfilment. We argue in this regard that a strong sense of 
career embeddedness may be positively associated with high levels of affective commitment (i.e. an enhanced sense of attachment and belonging to the organisation and feeling positive about remaining in the organisation: Meyer \& Allen, 1997). The P-E fit theory (Guan et al., 2021) argues that the fulfilment of supplementary fit needs provides a coherent career identity that meets several psychological needs such as, inter alia, the need for belonging and the need for selfexpression.

\section{Method}

\section{Research participants}

The sample involved a convenience sample $(N=290)$ of employees employed in the services industry. The participants originated from Africa (South Africa: 70\%, Zimbabwe: $15 \%$ ) and Europe (15\%). Most of the participants had a tenure of more than 5 year $(60 \%)$ and were mainly in the establishment or maintenance phase of their careers (31-65 years: 74\%). The mean age of the sample was 38.58 years (standard deviation $[S D]=9.34$ ). In terms of ethnic origin, Black participants (African/Indian/Asian/mixed race) represented $63 \%$ of the sample. Male participants represented $54 \%$ and females $46 \%$ of the sample.

\section{Measuring instruments}

Career embeddedness: The CES developed by Ferreira and Coetzee (2020) measures two dimensions of career embeddedness: career development fit (nine items, e.g. 'My career needs are supported by people in the organisation') and career values fit (five items, e.g. 'My career values are compatible with my current organisation'). The 14 items are rated on 7-point Likert-type scale ( 1 = strongly disagree; 7 = strongly agree). Preliminary exploratory factor analysis by Ferreira and Coetzee (2020) identified the two-factor structure and high internal consistency reliability of the CES: career development fit $(\alpha=0.93)$, career values fit $(\alpha=0.92)$ and overall CES scale $(\alpha=0.94)$.

Affective commitment: The affective commitment subscale developed by Meyer and Allen (1997) is a self-rated scale, which consists of eight items (e.g. 'I do feel emotionally attached to this organisation'). A 5-point Likert-type scale $(1=$ strongly disagree; to $5=$ strongly agree $)$ is used. Construct validity and internal consistency reliability $(\alpha=0.84)$ for this measurement was confirmed by Meyer and Allen (1991) and Ferreira (2012).

\section{Research procedure}

Participants received an electronic link to the survey by email. Responses were captured on an Excel spreadsheet and converted into an Statistical Package for the Social Sciences (SPSS 2017) file for data analysis purposes.

\section{Statistical analysis}

Descriptive statistics, bivariate correlations, confirmatory factory analysis (CFA) and multiple regression analysis were performed by using SAS/STAT® software version 9.4M5@ (2017). Results were interpreted at the $95 \%$ confidence level interval (CI). The CFA was performed to assess the construct (convergent and discriminant) validity of the CES. The following guidelines (Hoxmeier, Nie, \& Purvis, 2000; Jöreskog \& Sörbom, 2002) were applied: The comparative fit index (CFI) should exceed 0.90, the root mean square error of approximation (RMSEA) and standardised root mean square residual (SRMR) should both be less than 0.05 (good) or 0.08 (acceptable) and the ratio of chi-square values to freedom degrees (df) should be less than 3.0 (good) or less than 5.0 (acceptable).

The Fornell and Larcker (1981) criterion of average variance extracted (AVE) of $>0.50$ and the composite reliability $(\mathrm{CR})$ values of $>0.70$, and standardised path estimates equal to or above 0.70 , were also applied as an indication of convergent validity. In line with the guidelines provided by Alarcòn and Sánchez (2015), heterotrait-monotrait (HTMT) ratio of correlations below 0.85 amongst the factors of the measurement model was additionally used as evidence of discriminant validity. Using the guidelines of Hair, Black, Babin and Anderson (2010), tolerance values higher than 0.20 , variance inflation factor (VIF) values lower than 3.0 and bivariate correlations below 0.80 were considered as evidence of a lack of multicollinearity.

\section{Ethical considerations}

Ethical clearance and permission to conduct the research were obtained from the management of the University of South Africa (Ethics certificate reference: ERC Ref\#: 2020 CEMS/IOP_014). The participants were invited to voluntarily participate in the research study. The online questionnaire included an informed consent form. The privacy, anonymity and confidentiality of all the participants were ensured and honoured. The participants gave informed consent for the group-based data to be used for research purposes.

\section{Results \\ Descriptive statistics}

As shown in Table 1, the mean levels of the CES ranged from 4.86 to 4.78 (mid-range; slightly agree) indicating low career embeddedness. The Cronbach's alpha coefficients and the composite reliability coefficients for the overall scale $(\alpha=0.94 ; \mathrm{CR}=0.98)$ and subscales were high: career development fit $(\alpha=0.93 ; \mathrm{CR}=0.93)$ and career values fit $(\alpha=0.92 ; \mathrm{CR}=0.92)$. These results suggested good construct reliability for the CES. The affective commitment scale also suggested good construct reliability ( $\alpha=0.84$; $\mathrm{CR}=0.84)$.

The bivariate correlations between the two CES subscales and the overall construct CES scale were for both subscales $r=0.95$ ( $p=0.0001$; large practical effect). The bivariate correlation between the career development fit subfactor and the career values fit subfactor was $r=0.81(p=0.0001$; 
TABLE 1: Descriptive statistics and bivariate correlations.

\begin{tabular}{|c|c|c|c|c|c|c|c|c|c|c|}
\hline & Scale variables & Cronbach's alpha & Composite reliability (CR) & AVE & Mean & SD & 1 & 2 & 3 & 4 \\
\hline 1 & Overall career embeddedness & 0.94 & 0.98 & 0.90 & 4.82 & 1.24 & - & - & - & - \\
\hline 2 & Career development fit & 0.93 & 0.93 & 0.61 & 4.78 & 1.33 & $0.95 * * *$ & - & - & - \\
\hline 3 & Career values fit & 0.92 & 0.92 & 0.79 & 4.86 & 1.28 & $0.95 * * *$ & $0.81 * * *$ & - & - \\
\hline 4 & Affective commitment & 0.84 & 0.84 & 0.42 & 4.48 & 1.28 & $0.68 * * *$ & $0.65 * * *$ & $0.64 * * *$ & - \\
\hline
\end{tabular}

AVE, Average variance extracted; SD, standard deviation

$N=290, * * *, p=0.000$.

TABLE 2: Confirmatory factor analysis: Career embeddedness scale.

\begin{tabular}{lcccccccc}
\hline Model & $\begin{array}{c}\text { Chi- } \\
\text { square }\end{array}$ & $\boldsymbol{d} f$ & $\begin{array}{c}\text { Chi- } \\
\text { square/df }\end{array}$ & RMSEA & SRMR & CFI & AIC \\
\hline Model 1 & 468.84 & 77 & 6.09 & 0.000 & 0.13 & 0.06 & 0.88 & 524.80 \\
Model 2 & 365.35 & 76 & 4.81 & 0.000 & 0.12 & 0.06 & 0.91 & 423.30 \\
Model 3 & 238.25 & 53 & 4.50 & 0.000 & 0.11 & 0.04 & 0.94 & 288.30 \\
\hline
\end{tabular}

Note: $N=290$.

RMSEA, root mean square error of approximation; SRMR, standardised root mean square residual; CFI, comparative fit index; AIC, Akaike information criterion.

large practical effect). The correlation suggested that potential issues of multicollinearity were not a serious threat to the interpretation of the findings. The correlation was high but in line with the threshold cut-off for possible multicollinearity amongst the two subfactors.

The bivariate correlations between the CES scale and subscales and the affective commitment scale ranged between $r=0.64$ and $r=0.68(p=0.000$; large practical effect), indicating lack of multicollinearity as per the guidelines of Hair et al. (2010).

\section{Construct validity of the career embeddedness scale}

Table 1 shows that the AVE values for the two subscales were above $>0.50$ and at an acceptable level. Combined, as guided by the Fornell and Larcker (1981) criterion, the AVE values of $>0.50$ and the CR values of $>0.70$ (shown in Table 1 ) indicated convergent validity of the CES. Table 1 further shows that the bivariate correlations amongst the overall CES factor and its two subfactors are significantly greater than zero $(r=0.95 ; p=0.000)$, indicating nomological validity.

The construct (convergent and discriminant) validity of the CES was further inspected by means of three CFA models:

- Model 1: A one-factor CFA was performed with all items of the CES scale loading onto one factor.

- Model 2: A two-factor CFA was performed with the items loading onto each of their respective subscales and then loading onto the overall career embeddedness factor.

- Model 3: An optimised two-factor CFA was performed with items loading onto each of their respective subscales, and the two subscale factors then loading onto the overall career embeddedness factor. The following two items of the career values fit subfactor were excluded from this model (item 10 and 11).

The model fit indices are reported in Table 2. The fit indices for the one-factor CFA indicated poor model fit: $\chi^{2} / \mathrm{df}=6.09$, RMSEA $=0.13$, SRMR $=0.06$, CFI $=0.88$ and Akaike
TABLE 3: Standardised path coefficients of the career embeddedness scale.

\begin{tabular}{|c|c|c|c|c|}
\hline \multicolumn{2}{|l|}{ Path } & \multirow{2}{*}{$\begin{array}{c}\begin{array}{c}\text { Standardised } \\
\text { estimate }\end{array} \\
0.83\end{array}$} & \multirow{2}{*}{$\begin{array}{c}\begin{array}{c}\text { Standard } \\
\text { error }\end{array} \\
0.09\end{array}$} & \multirow{2}{*}{$\begin{array}{c}p \\
<0.0001\end{array}$} \\
\hline $\begin{array}{l}\text { Career } \\
\text { development } \\
\text { fit }\end{array}$ & $\begin{array}{l}\text { Item } 1 \text { (B7.1) } \\
\text { I like my current career } \\
\text { progress within the } \\
\text { organisation }\end{array}$ & & & \\
\hline & $\begin{array}{l}\text { Item } 2 \text { (B7.5) } \\
\text { I am curious about future } \\
\text { career options in the } \\
\text { organisation }\end{array}$ & 0.51 & 0.09 & $<0.0001$ \\
\hline & $\begin{array}{l}\text { Item } 3 \text { (B7.6) } \\
\text { I feel my career needs are } \\
\text { respected by my colleagues }\end{array}$ & 0.79 & 0.08 & $<0.0001$ \\
\hline & $\begin{array}{l}\text { Item } 4 \text { (B7.7) } \\
\text { I have a network of support } \\
\text { that helps me grow in my } \\
\text { career }\end{array}$ & 0.76 & 0.08 & $<0.0001$ \\
\hline & $\begin{array}{l}\text { Item } 5 \text { (B7.8) } \\
\text { My career needs are } \\
\text { supported by people in the } \\
\text { organisation }\end{array}$ & 0.89 & 0.09 & $<0.0001$ \\
\hline & $\begin{array}{l}\text { Item } 6 \text { B7.9) } \\
\text { I feel positive about the } \\
\text { network of career } \\
\text { development support } \\
\text { structures offered by the } \\
\text { organisation }\end{array}$ & 0.91 & 0.09 & $<0.0001$ \\
\hline & $\begin{array}{l}\text { Item } 7 \text { (B7.12) } \\
\text { My career in this organisation } \\
\text { offers excellent promotional } \\
\text { opportunities }\end{array}$ & 0.78 & 0.09 & $<0.0001$ \\
\hline & $\begin{array}{l}\text { Item } 8 \text { (B7.13) } \\
\text { My career in this organisation } \\
\text { offers excellent continuous } \\
\text { learning and upskilling } \\
\text { opportunities }\end{array}$ & 0.81 & 0.09 & $<0.0001$ \\
\hline & $\begin{array}{l}\text { Item } 9 \text { (B4.14) } \\
\text { My career in this organisation } \\
\text { helps me to uphold my } \\
\text { marketability and } \\
\text { employability }\end{array}$ & 0.72 & - & $<0.0001$ \\
\hline \multirow[t]{3}{*}{$\begin{array}{l}\text { Career } \\
\text { values fit }\end{array}$} & $\begin{array}{l}\text { Item } 10 \text { (B7.2) } \\
\text { I feel my career needs fit in } \\
\text { well with the opportunities } \\
\text { offered by the organisation }\end{array}$ & 0.89 & 0.06 & $<0.0001$ \\
\hline & $\begin{array}{l}\text { Item } 11 \text { (B7.3) } \\
\text { My career needs fit in well } \\
\text { with the culture of the } \\
\text { organisation }\end{array}$ & 0.93 & 0.05 & $<0.0001$ \\
\hline & $\begin{array}{l}\text { Item } 12 \text { (B7.4) } \\
\text { My career values are } \\
\text { compatible with my current } \\
\text { organisation's values }\end{array}$ & 0.84 & - & $<0.0001$ \\
\hline $\begin{array}{l}\text { Career } \\
\text { embeddedness }\end{array}$ & Career development fit & 1.02 & 0.07 & $<0.0001$ \\
\hline $\begin{array}{l}\text { Career } \\
\text { embeddedness }\end{array}$ & Sareer values fit & 0.87 & 0.07 & $<0.0001$ \\
\hline
\end{tabular}

information criterion $(\mathrm{AIC})=524.80$. The second and third CFA had acceptable model fit with the data: Model 2: $\chi^{2} / \mathrm{df}=$ 4.81, $\mathrm{RMSEA}=0.12, \mathrm{SRMR}=0.06, \mathrm{CFI}=0.91, \mathrm{AIC}=423.30$, Model 3: $\chi^{2} / \mathrm{df}=4.49$, RMSEA $=0.11$, SRMR $=0.04, \mathrm{CFI}=$ 0.94, $\mathrm{AIC}=288.30$. The AIC values indicated lowest estimates for Model 3. However, both CFA Model 2 and CFA Model 3 were regarded as having acceptable model fit with the data set. The good fit of the data of the two factor CFA models as opposed to the lack of fit of the data of the 
one-factor CFA model indicated acceptable discriminant validity of the CES.

The path estimates for CFA Model 3 were further inspected to assess convergent validity of the CES. Table 3 shows that all the standardised path estimates were significant and above 0.70 (except for item 2 of the career development fit = 0.51). Taken together with the AVE estimates that were above 0.50 , the results provided evidence of convergent validity of the CES. The two factors also revealed strong loadings on the overall career embeddedness construct $(>0.70)$. Overall, the results suggested adequate convergent validity of the CES.

\section{Career embeddedness as a valid predictor of affective commitment}

The data of the CES CFA Model 3 was used in the regression analysis. As shown in Table 4, we first tested the discriminant validity amongst the three factors (career development fit, career values fit and affective commitment) of the measurement model before conducting the regression analysis. Table 4 shows that the measurement Model 3 had good discriminant validity:

- Model 1: A one-factor CFA was performed with all three constructs (career development fit, career values fit and affective commitment) loading onto one factor.

- Model 2: A multi-factor CFA was performed with the items loading onto each of their respective subscales (career development fit, career values fit and affective commitment).

- Model 3: An optimised multi-factor CFA was performed with items loading onto each of their respective subscales (career development fit, career values fit and affective

TABLE 4: Confirmatory factor analysis: Measurement model.

\begin{tabular}{lcccccc}
\hline Model & CMIN $/ \boldsymbol{d f}$ & $\boldsymbol{p}$ & RMSEA & SRMR & CFI & AIC \\
\hline Model 1 & 6.52 & 0.000 & 0.14 & 0.09 & 0.79 & 1188.80 \\
Model 2 & 4.69 & 0.000 & 0.11 & 0.07 & 0.86 & 869.70 \\
Model 3 & 3.45 & 0.000 & 0.09 & 0.04 & 0.94 & 366.40 \\
\hline
\end{tabular}

Note: $N=290$.

CMIN, chi-square fit statistics; $d f$, degree of freedom; RMSEA, root mean square error of approximation; SRMR, standardised root mean square residual; CFI, comparative fit index AIC, Akaike information criterion.

TABLE 5: Discriminant validity - heterotrait-monotrait ratio of correlations.

\begin{tabular}{lccc}
\hline $\begin{array}{l}\text { Measurement model } \\
\text { factors }\end{array}$ & $\begin{array}{c}\text { Career } \\
\text { development fit }\end{array}$ & Career values fit & $\begin{array}{c}\text { Affective } \\
\text { commitment }\end{array}$ \\
\hline Career development fit & 1.000 & - & - \\
Career values fit & 0.90 & 1.000 & - \\
Affective commitment & 0.75 & 0.79 & 1.000 \\
\hline
\end{tabular}

Note: $N=290$. commitment). Four reversed scored items of the affective commitment scale were removed. The adjusted CES scale was used in the regression analysis.

We also inspected the HTMT ratio of correlations amongst the three factors of the measurement model to test whether the true correlation between the three constructs differ. Table 5 shows that the HTMT values between the two CES factors and the ACS factor were all smaller than 1.00 and below the threshold value of 0.85 , and thus provided additional evidence of discriminant validity between the CES and ACS (Alarcòn \& Sánchez, 2015).

Overall, the regression results provided evidence of the predictive validity of the CESs and its two subfactors for the present sample. Table 6 shows that the analysis of variance (ANOVA) was practically significant for Model 1 (career development fit and career values fit regressed onto affective commitment): $F=120.68 ; p=0.000 ; R^{2}=$ 0.45 (large practical effect). Multicollinearity was inspected in terms of the tolerance values and VIFs for Model 1. The tolerance values were higher than 0.20 , and the VIF values were lower than 3.0 which, according to the guidelines of Hair et al. (2010), showed that multicollinearity was not a serious threat to the findings. The career development fit variable $(\beta=0.39 ; p=0.000)$ obtained a slightly higher beta value than the career values fit variable $(\beta=0.33 ; p=0.000)$ in explaining the variance in affective commitment.

Table 6 shows that the ANOVA for Model 2 (overall career embeddedness construct regressed onto affective commitment) was also practically significant: $F=242.03 ; p=0.000 ; R^{2}=0.46$ (large practical effect). Overall career embeddedness $(\beta=0.68$; $p=0.000)$ significantly explained the variance in affective commitment.

\section{Discussion}

The study provided support for the validity of the CES of Ferreira and Coetzee (2020) as a predictor of affective commitment. The first contribution of the study is its exploration of the theoretical P-E fit function of career embeddedness and the construct validity of the CES. The study's findings provided evidence of good internal consistency reliability, convergent, nomological and discriminant validity of the CES for the present sample.

The second contribution of this study was exploring the association between career embeddedness and affective

TABLE 6: Multiple regression of career embeddedness onto affective commitment.

\begin{tabular}{|c|c|c|c|c|c|c|c|c|c|}
\hline \multirow[t]{2}{*}{ Model } & & \multirow{2}{*}{$\begin{array}{c}\text { Standardised } \\
\boldsymbol{\beta} \\
\end{array}$} & \multirow{2}{*}{$\begin{array}{c}\text { Unstandardised } \\
\boldsymbol{\beta} \\
\end{array}$} & \multirow{2}{*}{$\begin{array}{l}\mathrm{Cl} 95 \% \text { (lower; } \\
\text { upper) }\end{array}$} & \multirow[t]{2}{*}{ SE } & \multirow[t]{2}{*}{$t$} & \multicolumn{2}{|c|}{ Model information } & \multirow[t]{2}{*}{ Adjusted $R^{2}$} \\
\hline & & & & & & & $\mathrm{Fp}$ & $p$ & \\
\hline \multirow[t]{2}{*}{1} & Career development fit & 0.39 & 0.37 & $0.23 ; 0.51$ & 0.07 & $5.19 * * *$ & 120.68 & 0.000 & 0.45 \\
\hline & Career values fit & 0.33 & 0.33 & $0.18 ; 0.47$ & 0.08 & $4.38 * * *$ & - & - & - \\
\hline 2 & Overall career embeddedness & 0.68 & 0.70 & $0.61 ; 0.79$ & 0.05 & $15.56 * * *$ & 242.03 & 0.000 & 0.46 \\
\hline
\end{tabular}

Note: $N=290$.

$\mathrm{Cl}$, confidence interval; $\mathrm{SE}$, standard error.

$* * *, p=0.000$. Model 1 : Tolerance values $=0.34$. Variance inflation factor values $=2.91$. 
commitment. The CES (Ferreira \& Coetzee, 2021) construct of career embeddedness was shown to be a distinctive construct from Meyer and Allen's (1997) construct of affective commitment. In this regard, the study deepened understanding of the psychological conditions of career embeddedness that elucidate individuals' emotional attachment and identification with the organisation. Specifically, the best fitting bifactor CES CFA and regression models suggested that career embeddedness is a hierarchical construct with global career embeddedness as the higher order factor, and its two secondary facets accounting for substantial variance in individuals' affective commitment. Each facet of career embeddedness (career development fit and career values fit) represents a specific $\mathrm{P}-\mathrm{E}$ fit condition that explains affective commitment.

The findings showed that individuals' affective commitment results from a complex interplay of positive views about Guan et al.'s (2021) notion of D-A fit and N-S fit involving career development support structures, promotional and upskilling opportunities, career-supportive relations and a match between personal career and organisational values (supplementary fit). This finding is in agreement with research showing that organisational career-supportive conditions and perceptions of mutual reciprocity involving success expectations, competence development, belongingness and career goal attainment support are positively associated with affective commitment (Allen \& Meyer, 1990; Coetzee \& Bester, 2021; Meyer \& Allen, 1991, 1997).

Overall, our study enriches P-E fit theory and empirical research on $\mathrm{P}-\mathrm{E}$ fit by exploring the recent construct of career embeddedness as a measure of facets of Guan et al.'s (2021) notion of supplementary fit, and D-A fit and $\mathrm{N}-\mathrm{S}$ fit and the association with individuals' psychological attachment to the organisation. Our study findings suggest that for organisations concerned with raising the affective commitment of their employees, the two facets of career embeddedness may serve as important indicators of the quality of the P-E fit interaction. Each of the two facets of career embeddedness provides specific value for the development of career embeddedness profiles and the prediction of affective commitment.

Using the CES as a measure of the degree to which organisational career support conditions fulfil individuals' psychological career needs potentially provides opportunity for engagement with the organisation and individual on career development issues in response to workplace changes that potentially affect employees' psychological attachment to the organisation (Akkermans et al., 2020; De Lucas Ancillo, Del Val Nunez, \& Gavrila, 2020; Guan et al., 2021; Guo, Wang, \& Wang, 2021). Generally, our study findings suggest that emotional identification with the organisation becomes more salient as individuals become more situated in their careers in the organisation. Organisational career-supportive practices, culture and values facilitate deep-seated situatedness in the organisational-based career because of favourable P-E fit conditions that enable career needs fulfilment (Guan et al., 2021; Guo et al., 2021).
The findings indicate the potential for further replication studies by scholars across the world for further refinement of the construct validity and the testing of the predictive validity of the CES in relation to other career constructs. The CES may be valuable for research on a larger scale including groups from different populations, occupational and country contexts.

The findings should be considered in the context of the study's limitations. Causal inferences cannot be made because of the use of self-reported cross-sectional data in our study. Future longitudinal studies could test the testretest reliability and construct validity of the CES (Ferreira \& Coetzee, 2021) in different populations, occupations and countries. It will also be useful for future longitudinal research to assist with tracking change in terms of career embeddedness as a result of career support interventions or employment context changes over time. Despite these limitations, the study provides a starting point for exploring career embeddedness as a useful construct in the unprecedented career world of the 2020s.

\section{Conclusion}

In conclusion, this study gives valuable psychometric information on the CES (Ferreira \& Coetzee, 2020) and its application in the P-E fit theory and work context. Future research on the CES will also allow researchers to contribute to the debate on the nature of career embeddedness in the post-pandemic workplace.

\section{Acknowledgements Competing interests}

The authors declare that they have no financial or personal relationships that may have inappropriately influenced them in writing this article.

\section{Authors' contributions}

N.F., M.C. and I.P. all contributed equally to the conceptual framework, data collection and analysis and writing of the research article.

\section{Funding information}

The authors received no financial support for the research, authorship, and/or publication of this article.

\section{Data availability}

The authors confirm that the data supporting the findings of this study are available within the article.

\section{Disclaimer}

The views and opinions expressed in this article are those of the authors and do not necessarily reflect the official policy or position of any affiliated agency of the authors, and the publisher. 


\section{References}

Abessolo, M., Hirschi, A., \& Rossier, J. (2021). Development and validation of multidimensional career values questionnaire: A measure integrating work values, career orientations, and career anchors. Journal of Career Development, 48(3), 243-259. https://doi.org/10.1177/0894845319846567

Ackerman, P.L., \& Kanfer, R. (2020). Work in the 21st century: New directions for aging and adult development. American Psychologist, 75(4), 486-498. https://doi. org/10.1037/amp0000615

Akkermans, J., Richardson, J., \& Kraimer, A. [Editorial]. (2020). The covid-19 crisis as a career shock: Implications for careers and vocational behaviour. Journal of Vocational Behavior, 119, 103434. https://doi.org/10.1016/j.jvb.2020.103434

Alarcòn, D., \& Sánchez, J.A. (2015). Assessing convergent and discriminant validity in the ADHD-R IV rating scale. Universidad Pablo de Olavide. Retrieved from https:// www.stata.com/meeting/spain15/abstracts/materials/spain15_alarcon.pdf

Allen, N.J., \& Meyer, J.P. (1990). The measurement and antecedents of affective, continuance and normative commitment to the organization. Journal of Occupational

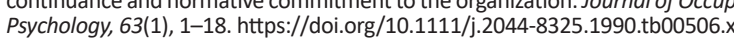

Cho, E. [Editorial]. (2020). Examining boundaries to understand the impact of COVID-19 on vocational behaviors. Journal of Vocational Behavior, 119, 103437. https://doi.org/10.1016/j.jvb.2020.103437

Coetzee, M. (2018). Career development and organizational support. In Oxford research encyclopedia of business and management, August (pp. 1-16). Oxford: Oxford University Press.

Coetzee, M., \& Bester, S.M. (2021). Exploring the reciprocal correspondence among workplace relationships, career goal instrumentality, career satisfaction, and organisational commitment. South African Journal of Psychology, 51(1), 81-94. https://doi.org/10.1093/acrefore/9780190224851.013.168

Coetzee, M., \& Schreuder, A.M.G. (2021). Careers: An organisational perspective (6th ed.). Cape Town: Juta.

Darrow, J.B., \& Behrend, T.S. (2017). Person-environment fit is a formative construct. Journal of Vocational Behavior, 103, 117-131. https://doi.org/10.1016/j. jvb.2017.08.007

De Lucas Ancillo, A., Del Val Nunez, M.T., \& Gavrila, S.G. (2020). Workplace change within the COVID-19 context: A grounded theory approach. Economic Research, 34(1), 2297-2316. https://doi.org/10.1080/1331677X.2020.1862689

Durr, II. M.R., \& Tracey, T.J.G. (2009). Relation of person-environment fit to career certainty. Journal of Vocational Behavior, 75, 129-138. https://doi.org/10.1016/j. jvb.2009.05.003

Ferreira, N. (2012). Constructing a psychological career profile for staff retention. Unpublished doctoral thesis, University of South Africa, Pretoria.

Ferreira, N., \& Coetzee, M. (2020). Exploratory factor analysis of the career embeddedness scale. Unpublished research report. University of South Africa.

Fornell, C., \& Larcker, D.F. (1981). Evaluating structural equation models with unobservable variables and measurement error. Journal of Marketing Research, 18, 39-50. https://doi.org/10.1177/002224378101800104

Guan, Y., Deng, H., Fan, L., \& Zhou, X. (2021). Theorizing person-environment fit in a changing career world: Interdisciplinary integration and future directions. Journa of Vocational Behavior, 126, 103557. https://doi.org/10.1016/j.jvb.2021.103557

Guo, W., Wang, L., \& Wang, N. (2021). Research on the impact of career management fit on career success. Asia Pacific Journal of Human Resources, 59, 279-304. https://doi.org/10.1111/1744-7941.12236

Hair, J.F., Black, W., Babin, B.J., \& Anderson, R.E. (2010). Multivariate data analysis: A global perspective (7th ed.). London: Pearson.

Hall, D.T., Yip, J., \& Doiron, K. (2018). Protean careers at work: Self-direction and values orientation in psychological success. Annual Review of Organizational Psychology and Organizational Behavior, 5, 129-156. https://doi.org/10.1146/annurevorgpsych-032117-104631

Holtom, B.C., \& Darabi, T. (2018). Job embeddedbess theory as a tool for improving employee retention. In M. Coetzee, I.L. Potgieter, \& N. Ferreira (Eds.), Psychology of retention: Theory, research and practice (pp. 95-117). Basingstoke: Springer Nature.

Hoxmeier, J.A., Nie, W., \& Purvis, G.T. (2000). The impact of gender and experience on user confidence in electronic mail. Journal of End User Computing, 12(4), 11-21. https://doi.org/10.4018/joeuc.2000100102

Huang, H., Cheng, L., Sub, P., Jiang, Y.S., \& Lin, H.H. (2021). Relationship among social tactics, job embeddedness, and affective commitment in newcomers: The moderating effect of workplace spirituality. Journal of Management \& Organization, 2021, 1-12. https://doi.org/10.1017/jmo.2021.11
Jiang, Z. (2017). Social support and career psychological states: An integrative model of person-environment fit. Journal of Career Assessment, 25(2), 219-237. https:// of person-environment fit. Journal of
doi.org/10.1177/1069072715621019

Jiang, Z., \& Jiang, X. (2015). Core self-evaluation and life satisfaction: The personenvironment fit perspective. Personality and Individual Differences, 75, 68-73. https://doi.org/10.1016/j.paid.2014.11.013

Jöreskog, K.G., \& Sörbom, D. (2002). LISREL 8: Structural equation modeling with the SIMPLIS command language. Lincolnwood: Scientific Software International.

Kooij, D.T.A.M. (2020). The impact of the covid-19 pandemic on older workers: The role of self-regulations and organizations. Work, Aging and Retirement, 6(4), 233-237. https://doi.org/10.1093/workar/waaa018

Kooij, D., Zacher, H., Wang, M., \& Heckhausen, J. (2020). Successful aging at work: A process model to guide future research and practice. Industrial and Organizational Psychology: Perspectives on Science and Practice, 13, 345-365. https://doi. org/10.1017/iop.2020.1

Malinin, L.H. (2016). Creative practices embodied, embedded, and enacted in architectural settings: Toward an ecological model of creativity. Frontiers in Psychology, 6, 1978. https://doi.org/10.3389/fpsyg.2015.01978

Meyer, J.P., \& Allen, N.J. (1991). A three-component conceptualisation of organisational commitment. Human Resource Management Review, 1(1), 61-89. organisational commitment. Human Resource
https:/doi.org/10.1016/1053-4822(91)90011-Z

Meyer, J.P., \& Allen, N.J. (1997). Commitment in the workplace: Theory, research and application. Thousand Oaks, CA: Sage.

Mitchell, T., Holtom, B., Lee, T., Sablynski, C., \& Erez, M. (2001). Why people stay: Using job embeddedness to predict voluntary turnover. Academy of Management Journal, 44, 1102-1121. https://doi.org/10.2307/3069391

Potgieter, I.L., Coetzee, M., \& Ferreira, N. (2019). The role of career concerns and workplace friendship in the job embeddedness-retention practices satisfaction link. South African Journal of Industrial Psychology, 44(0), a1519. https://doi. org/10.4102/sajip.v44i0.1519

Restubog, S.L., Ocampo, A.C.G., \& Wang, L. [Editorial] (2020). Taking control amidst chaos: Emotion regulation during COVID-19. Journal of Vocational Behavior, 119, 103440. https://doi.org/10.1016/j.jvb.2020.103440

Rhoades, L., \& Eisenberger, R. (2002). Perceived organizational support: A review of the literature. Journal of Applied Psychology, 87(4), 698-714. https://doi. org/10.1037//0021-9010.87.4.698

Sampaio, C., Cardoso, P., Rossier, J., \& Savickas, M.L. (2021). Attending to clients' psychological needs during career construction counselling. The Career Development Quarterly, 69, 96-113. https://doi.org/10.1002/cdq.12252

SAS version 9.4M5@. (2017). SAS/STAT ${ }^{\circledR}$ software. Cary, NC: SAS Institute Inc.

Savickas, M.L. (2013). Career construction theory and practice. In R.W. Lent \& S.D. Brown (Eds.), Career development and counselling: Putting theory and research to work (2nd ed., pp. 147-183). Hoboken, NJ: John Wiley \& Sons.

Sungu, L.J., Weng, Q., \& Kitule, J.A. (2019). When organizational support yield both performance and satisfaction: The role of performance ability in the lens of social exchange theory. Personnel Review, 48(6), 1410-1428. https:/doi.org/10.1108/ PR-10-2018-0402

Super, D.E. (1990). A life-span, life-space to career development. In D. Brown, L. Brooks, \& Associates (Eds.), Career choice and development (2nd ed., pp. 197261). Hoboken, NJ: Jossey-Bass.

Vantilborgh, T., Bidee, J., Pepermans, R., Willems, J., Huybrechts, G., \& Jegers, M. (2013). From 'getting' to 'giving': Exploring age-related differences in perceptions of and reactions to psychological contract balance. European Journal of Work and Organizational Psychology, 22(3), 293-305. https://doi.org/10.1080/135943 2X.2012.721354

Van Vianen, A.E.M. (2018). Person-environment fit: A review of its basic tenets. Annual Review Organizational Psychology and Organizational Behaviour, 5, 75-101. Retrieved from https://doi.org/10.1146/annurev-orgpsych-032117104702

Vondracek, F.W., Ford, D.H., \& Porfeli, E.J. (2014). A living systems theory of vocational behavior and development. Rotterdam: Sense Publishers.

Weng, Q., Wu, S., McElroy, J.C., \& Chen, L. (2018). Place attachment, intent to relocate and intent to quit: The moderating role of occupation commitment. Journal of Vocational Behavior, 108, 78-91. https://doi.org/10.1016/j.jvb.2018.06.002

$\mathrm{Xu}, \mathrm{H}$., \& Tracey, T.J. (2014). The role of ambiguity tolerance in career decision making. Journal of Vocational Behavior, 85, 18-26. https://doi.org/10.1016/j. jvb.2014.04.001

Zhu, D., Kim, P.B., Milne, S., \& Park, I. (2021). A meta-analysis of career commitment. Journal of Career Assessment, 29(3), 502-524. https://doi.org/10.1016/j. jvb.2014.04.001 